\title{
A PÁRTFOGÓ FELÜGYELET VÉGREHAJTÁSA ÉS HATÉKONYSÁGÁNAK KÉRDÉSKÖRE A PÁRTFOGOLTAK OLDALÁRÓL EGY EMPIRIKUS KUTATÁS TÜKRÉBEN
}

Szerző:

\author{
Molnár Fanni \\ Debreceni Egyetem, GYGYK \\ Első szerző e-mail címe: \\ molnarfannii97@gmail.com
}

\section{Lektorok:}

\author{
Gortka-Rákó Erzsébet $(\mathrm{PhD})$ \\ Debreceni Egyetem (Magyarosrszág) \\ Bocsi Veronika (PhD, Habil.) \\ Debreceni Egyetem (Magyarosrszág)
}

Molnár Fanni (2019): A pártfogói felügyelet végrehajtása és hatékonyságának kérdésköre a pártfogoltak oldaláról egy empirikus kutatás tükrében. Különleges Bánásmód, 5. (3). 49-61.

DOI 10.18458/KB.2019.3.49

\begin{abstract}
Absztrakt
Jelen tanulmány elméleti síkon a pártfogó felügyelet rendszerét, gyakorlati szinten pedig a pártfogó felügyelet hatékonyságát vizsgálja a fiatalkorúak oldaláról. Kvalitatív kutatásunkban 10 fó fiatalkorú pártfogolttal, és 15 fő olyan javítóintézeti növendékkel készítettünk félig strukturált, akik már voltak pártfogó felügyelet alatt. A kutatás azon részét emeljük ki, ami adekvát a téma vonatkozásában. A fiatalok pártfogással kapcsolatos tapasztalatai alapján javaslatokat fogalmaztunk meg a pártfogó felügyelet hatékonyságának növelése érdekében.
\end{abstract}

Kulcsszavak: pártfogó felügyelet, bủnmegelőzés, tercier prevenció, fiatalkorúak

Diszciplinák: pedagógia, szociálpedagógia

\begin{abstract}
THE PROBATION SERVICE'S ENFORCEMENT AND EFFICIENCY IN THE VIEW OF JUVENILE OFFENDERS

This study investigates the probation service system on a theoritical level, and its' efficiency in the view of juvenile offenders on a practical level. In this qualitative research we made semi-structured interviews with 10 youthful protegees and 15 underaged from reformatory, who has already been part of the probation system. We discuss parts of the research which are adequate on the subject of the study. Based on the interviewees' experiences of the probation service we tried to collect suggestions to increase the efficiency of the probation service.
\end{abstract}

Keywords: probation service, crime prevention, tertiary prevention, juvenile offenders Disciplines: pedagogy, socialpedagogy 
A fiatalkori kriminális magatartás kialakulásának megelőzése meglehetősen komplex folyamat. A tercier prevenciót végzô intézmények azt a célt szolgálják, hogy azoknak a fiataloknak, akik már elkövettek valamilyen bűncselekményt, elősegítsék a társadalmi integrációját, és megelőzzék az újabb bűncselekmény elkövetését. A pártfogás tevékenysége, mint tercier prevenció nagy múltra tekint vissza, azonban a fó célja változatlan. A Pártfogó Felügyelői Szolgálatot 2003-ban hozta létre a kormány 1183/2002. (X.31.) határozatával az Igazságügyi Minisztérium irányítása alatt. A pártfogó felügyelet közösségi szankcióként van jelen, ami a „büntetőpolitika és a szociálpolitika határterületén mozog, ezért képes elősegíteni a különböző szakmák együttmúködését, és kapcsolatot teremteni az igazságszolgáltatási rendszer hagyományos és modern eszközei között" (Kerezsi, 2016, 914.). Jelen tanulmány első részében a pártfogó felügyelet rendszerét, és a pártfogoltak fóbb jellemzőit tekintjük át. A második részben egy általunk végzett kutatást mutatunk be a téma szempontjából adekvát részét kiemelve, amiben a fiatalkorúak pártfogó felügyelettel kapcsolatos tapasztalatait vizsgáltuk. Ezen kutatási eredmények alapján fogalmaztunk meg olyan javaslatokat, amik növelhetik a pártfogó felügyelet hatékonyságát.

\section{A pártfogó felügyelet tevékenységének rend-} szere

A 2012. évi a büntető törvénykönyvről szóló C. törvény (továbbiakban: Btk.) 63. § (1) bekezdés alapján a pártfogó felügyelet bírói intézkedések közé tartozik. Pártfogó felügyeletet fiatalkorúakra tekintettel a következő szankciók esetében kötelező elrendelni: próbára bocsátás, jóvátételi munka, feltételes ügyészi felfüggesztés, szabadságvesztés felfüggesztésének próbaideje, feltételes szabadság tartama, illetve javítóintézetből történő ideiglenes elbocsátás esetén. Ez utóbbiak - a javítóintézetek - a gyermekvédelem speciális ellátórendszeréhez tartoznak. Ezekben a bíróság által javítóintézeti nevelésbe utalt, illetve az előzetes letartóztatásba helyezett bűnelkövető fiatalok élnek. Ezeknek a fiatalkorúaknak, mivel bűnelkövetők, az eredményes nevelése csak intézményi körülmények között valósítható meg. A fiatalkorúak előzetes letartóztatásuk idejét 1996. május 1. óta töltehetik javítóintézetekben (Rákó, 2011).

A megelőző pártfogás jogintézménye 2015. január elseje óta hatályos. A megelőző pártfogás gyermekvédelmi hatósági intézkedés, aminek bevezetésével a jogalkotó szándéka az volt, hogy a gyermekvédelmi és az igazságszolgáltatási rendszer hatékonyan együtt tudjon múködni a mellett, hogy mind a két rendszer meg tudja őrizni saját struktúráját. A megelőző pártfogás eljárásában részt vesz a gyámhatóság, a pártfogó felügyelő és a gyermekjóléti központ (Herke-Fábos, 2018). A 1997. évi a gyermekek védelméről és a gyámügyi igazgatásról szóló XXXI. törvény (továbbiakban: Gyvt.) 68/D. § (1) bekezdése alapján a bűncselekményt vagy szabálysértést észlelő hatóság jelzést ad a gyámhatóságnak, ami következtében elindul a védelembe vétel, vagy a már fenn álló védelembe vétel mellett megkeresi a pártfogó felügyelői szolgálatot környezettanulmány elkészítésére, illetve a veszélyeztetettség felmérésére. A Gyvt. 68/D. § (4) bekezdése alapján a gyermek kriminális szempontú veszélyeztetettségének magas foka esetén a gyámhatóság elrendeli a megelốzô pártfogást, kötelezi a gyermeket és a szülőket az együttmúködésre, továbbá a magatartási szabályok betartására. A veszélyeztetettség közepes foka esetén a gyámhatóság a körülményeket figyelembe véve elrendelheti a megelőző pártfogást. Ha a gyámhatóság nem rendeli el a megelőző pártfogást, akkor fél év múlva felülvizsgálja a döntést, és ha veszélyeztetettség növekedését tapasztalja, akkor újból felkeresi a pártfogó felügyelőt (Gyvt. 68/D. § (5) bekezdés). A megelőző pártfogással kapcsolatban 
számos kérdés vetôdik fel. Az egyik ilyen kérdéses pont, hogy a megelőző pártfogás biztosít-e lehetőséget arra, hogy a gyermek ne kerüljön túl korán az igazságszolgáltatás rendszerébe, vagy pedig egy újabb stigmával sújtja a gyermeket. A megelőző pártfogás elrendelése esetén a büntetőeljárás sok esetben lezajlik, tehát ezek a gyermek nem mentesülnek az igazságszolgáltatás korai beavatkozásának káros hatásai alól (Kerezsi és mtsai., 2015).

A következőkben áttekintjük a pártfogó felügyelők munkáját. A pártfogó felügyelői tevékenységek közé tartozik a környezettanulmány és kockázatértékelés (továbbiakban: környezettanulmány) készítése, ami fiatalkorúak esetén a gyanúsítottként történő kihallgatás után kötelezően beszerzendő bizonyítási eszköz (2017. évi XC. törvény a büntetőeljárásról 683-684. §). A környezettanulmány az elkövető életkörülményeire, személyiségére és fizikai állapotára fókuszál. A környezettanulmány feltárja a fiatalkorú korábbi bűncselekményére vonatkozó adatokat; családi és lakhatási körülményeit; iskolával, baráti körrel, szabadidős tevékenységekkel, káros szenvedélyekkel kapcsolatos információkat; fizikai és mentális állapotára, magatartására vonatkozó megállapításokat, illetve a fiatalkorú bűncselekményhez való viszonyulását. A pártfogó felügyelő a környezettanulmány tartalmának egyes csoportköreit követően, továbbá a környezettanulmány végén összesítve háromszintủ kockázatértékelést végez. A veszélyeztetettség foka lehet alacsony, közepes vagy magas. A 8/2013. (VI. 29.) a Pártfogó Felügyelői Szolgálat tevékenységérôl szóló KIM rendelet 16/B. § alapján magas veszélyeztetettség esetén elrendelik a megelőző pártfogást, ha arra nincs kizáró ok, közepes veszélyeztetettség esetén a pártfogó felügyelő javaslatot tehet a pártfogó felügyelet elrendelésére, vagy ha ezt nem teszi meg, akkor javasolhatja egyéb intézmények, személyek közreműködését. A 2017. évi a büntetőeljárásról szóló XC. törvény (továbbiakban: Be.) 684. § (4) bekezdése alapján a pártfogó felügyelőnek szükséges pedagógiai szak- véleményt beszereznie, illetve feltárni a gyermekvédelmi előzményeket. Ezt a pártfogó felügyelőnek úgy kell beszerezni, hogy a fiatalkorút az iskolában ne érje hátrány (Kerezsi, 2016). Fontosnak tartjuk megemlíteni a kockázatértékeléssel kapcsolatos aggályokat. Az egyik ilyen problémás pont, hogy a kockázatértékelés változói nem veszik figyelembe a kulturális különbségeket, ami torzíthatja az eredményeket és diszkriminatívan hathat a nemzetiségekre, mélyszegénységben élőkre. Egy másik problémás pont a kockázatértékelés elkészítésével kapcsolatban, hogy a kockázatértékelés, ami jelentős elméleti és módszertani ismeretek alkalmazását igényli, nagyban megnehezíti a pártfogó felügyelők munkáját, akik így is túlterheltséggel küzdenek (Kerezsi és mtsai., 2015).

A környezettanulmány mellett fontos dokumentum a pártfogó felügyelôii vélemény, aminek elkészítését az ügyészség, vagy a bíróság rendelhet el. A Be. kötelezővé teszi a pártfogó felügyelői vélemény elkészitésének elrendelését feltételes ügyészi felfüggesztés esetén (Be. 690. § (3) bekezdés). A Be. 203. $\S$ (1) bekezdése szerint a pártfogó felügyelői vélemény elkészítése során a pártfogó az alábbi körülményekre tér ki: családi körülményekre, egészségi állapotra, káros szenvedélyre, lakhatási körülményekre, iskolai végzettségre, jövedelmi, vagyoni viszonyaira, továbbá „bemutatja a feltárt tények, körülmények és a bűncselekmény elkövetése között fennálló kapcsolatot, a bűnismétlés kockázatait, valamint a terhelt szükségleteit" (Be. 203. § (1) bekezdés).

A pártfogó felügyelői vélemény végén a pártfogó felügyelő összegző véleményt ír. Ez kiterjed a bűnismétlés kockázatára, a fiatalkorú sajátos szükségleteire, a terhelt cselekményhez történő hozzáállására, a javasolt beavatkozásokra és ezek indoklására. A pártfogó felügyelői vélemény a környezettanulmányban fellelhető információkon túl részletesebben feltárja a bűnelkövető bűncselekményhez való hozzáállását, illetve a bűnismétlés kockázatát. 
A pártfogó felügyelet során végrehajtott esetkezelés egyik fontos momentuma a magatartási szabály. Megkülönböztetünk általános, és külön magatartási szabályokat. Az általános magatartási szabályok minden pártfogoltra érvényesek, mint például rendszeres kapcsolattartás a pártfogó felügyelővel, a határozatban előírt kötelezettségek betartása, a pártfogó felügyelő rendelkezéseinek betartása, továbbá a munkaképes elkövetőt munkába állásra kötelezi. A külön magatartási szabályok az elkövető személyiségéhez, illetve az általa elkövetett bủncselekményhez igazítva határozhatóak meg, amelyek elősegítik azt, hogy a gondozás individualizált formában valósuljon meg (Bogschütz és mtsai. 2009). A Btk. 71. § (2) bekezdése meghatároz külön magatartási szabályokat, amelyeket a bíróság, vagy az ügyészség rendelhet el. Ilyen külön meghatározott magatartási szabály például a bűntárssal történő kapcsolattartás megszakítása, a sértettől való távoltartás, nyilvános helyen fogyasztott alkohol tiltása, beleegyezése esetén gyógykezelésen való részvétel, vegyen részt pártfogó felügyelő által szervezett csoportfoglalkozáson.

A Btk. 71. § (3) bekezdése szerint ezeken kívül egyéb magatartási szabályokat is elő lehet írni a fiatalkorú személyiségére, elkövetetett bűncselekményre tekintettel, továbbá a társadalmi reintegrációt elősegítő magatartási szabályok is elrendelhetőek. Láthatjuk, hogy ezek a magatartási szabályok részben tiltó jellegűek, még egy másik része a társadalmi reintegrációt segíti elő (Bogschütz és mtsai. 2009). Ha a pártfogolt nem tartja be a magatartási szabályokat, annak jogi következményei vannak (pl. magatartási szabályok szigorítása, pártfogó felügyelet tartamának meghosszabbítása stb.). 2014-ben a pártfogó felügyelők az esetek 0,4\%ában jelezték a magatartási szabályok megszegését. Nem tudható, hogy az alacsony arányszám mögött a pártfogó felügyelői tevékenység eredményessége áll-e, vagy a pártfogó felügyelők túlterheltsége, ami következtében nem tudják megfelelően ellenôrizni a pártfogoltakat (Kerezsi, 2016).
Az igazságszolgáltatás során a fiatalkorúval kapcsolatba kerülő személyek közül a pártfogó felügyelő ismeri meg leginkább a fiatalkorút. A környezettanulmány és a pártfogó felügyelői vélemény elkészítése során közvetlen kapcsolatba kerül a fiatallal és környezetével, családjával, továbbá a pártfog felügyelő tölti a legtöbb időt együtt a fiatalkorúval. Ezt hátráltatja a pártfogó felügyelők leterheltsége, aminek következtében az együtt töltött idő minimálisra korlátozódik (Rosta, 2014).

A pártfogó felügyelő alaptevékenysége, hogy elősegítse a bűnismétlés megelőzését, ami szociális és pedagógiai szaktudást igényel. A pártfogó felügyelő a pártfogás ideje alatt egyéni esetkezelést végez, ami a klasszikus szociális munka egyik munkaformája, azonban a pártfogó felügyelők esetében ezt igazságügyi szociális munkának nevezik.

A klasszikus szociális munka és az igazságügyi szociális munka közti legjelentősebb különbség, hogy az elôbbi esetében a „probléma” megfogalmazása széles körben kiterjeszthetô, még az utóbbi esetében szűkebb keretben fogalmazódik meg. A pártfogó felügyelő a probléma-meghatározás középpontjába azt a kérdést teszi, hogy milyen tényezők vezettek a bűncselekmény elkövetéséhez és milyen lépéseket kell tenni annak érdekében, hogy megszűnjenek ezek a körülmények. Ha olyan tényezôk jelennek meg, amelyek kezelése túllépi a pártfogó kompetenciahatárát, célszerú a pártfogoltat a megfelelő szakemberhez irányítania. Jelentôs különbség még az, hogy a klasszikus szociális munkában általában jelen van az önkéntesség, ellenben az igazságügyi szociális munkában a kliens részvétele nem önkéntes, hanem kötelező, az esetben is végre kell hajtani, ha a pártfogolt nem együttmúködő.

$\mathrm{Az}$ esetkezelést megelőző pártfogás esetében a család- és gyermekjóléti központ esetmenedzserével együttmúködve kell végrehajtani (8/2013. (VI. 29.) a Pártfogó Felügyelői Szolgálat tevékenységéről szóló KIM rendelet 19/H. §). Az eset- 
kezelés folyamatát három szakaszra lehet felbontani.

Az első szakaszban a pártfogó felügyelő állapotfelmérést végez, feltárja a bűnelkövetéshez vezető okokat, veszélyeztető tényezőket. A feltárás tartalma szerint a következőekből áll: nem, kor, iskolai végzettség, személyiség jellemzői, motiváció, életmód, családstruktúra, szenvedélybetegség, lakhatási körülmények, kortárscsoportok, és szegregált helyzet.

A második szakaszban a pártfogó felügyelő elkészíti az egyéni pártfogó felügyelői tervet (továbbiakban: terv), amit szükséges a konkrét ügyre fókuszálva az egyéni sajátosságokhoz igazítani. A visszaeső bűnelkövetők esetében a pártfogó felügyelőnek növelni kell az esetkezelés intenzitását. Az esetkezelés intenzitása függ még az elrendelő döntésétől is példának okául a felfüg-gesztett szabadságvesztés esetén a pártfogolt ellenőrzése magasabb intenzitású, mint a próbára bocsátás esetén. A terv elkészítése az elrendelt pártfogó felügyelői időtartamra terjeszkedik ki, így a tervben megfogalmazott célokat erre az időkeretre tervezi meg a pártfogó felügyelő, rövid, közép és hosszú távú ütemterv keretein belül, amennyiben lehetőség van rá. Kulcsfontosságú a terv szempontjából az első fázis, mivel a pártfogó felügyelő a tervet azokra az információkra fogja alapozni. A terv a pártfogás idôszaka alatt módosulhat a változó körülmények függvényében. A harmadik szakaszban a terv végrehajtása történik meg. A fő vezérfonal a munkaerőpiaci integráció, a képzés, a lakhatási körülmények javítása, a szenvedélybetegség kezelése, és a pénzügyek rendezése.

Az egyéni esetkezelés mellett fontosnak tartjuk megemlíteni a csoportos igazságügyi szociális munkát. A pártfogó felügyelet reformja 2003-ban történt meg, aminek egyik szakmai célja volt, hogy az egyéni esetkezelés mellet megjelenjen a csoportos módszer is a pártfogó felügyelői tevékenységben. A 8/2013. (VI. 29.) a Pártfogó Felügyelói Szolgálat tevékenységéről szóló KIM rendelet 10. §
(1) bekezdés h) pontja alapján a pártfogó felügyelő „javaslatot tehet életvezetési készségek fejlesztésére irányuló csoportos vagy egyéni foglalkozáson való részvételére".

A csoportos foglalkozásnak számos előnye van, többek között a szociális készségek fejlesztése, a verbális és nonverbális kommunikációs képességek fejlesztése, az empátia növelése, az összetartozás élményének megélése, és a különböző szociális szerepek elsajátítása (Bogschütz és mtsai. 2009). A 8/2013. (VI. 29.) a Pártfogó Felügyelói Szolgálat tevékenységéról szóló KIM rendelet 56. § a) pontja szerint előnyben kell részesíteni a viselkedéskorrekcióra irányuló, illetve kompetencia-fejlesztésére irányuló csoportos vagy egyéni foglalkozásokat, különösen agresszió-helyettesítő tréninget, szociális készségfejlesztő tréninget, és munkaerőpiaci tréninget.

Látható, hogy a pártfogó felügyelők tevékenységük során célorientáltan igyekeznek a fiatalkorú bűnelkövetők kriminális magatartásához vezető okok kezelésére. Nem csupán felügyeletről, kontrollról van szó, hanem a pártfogolt életében megjelenő különböző diszfunkciók kezelési lehetőségeinek megteremtését is segítik azzal a céllal, hogy a fiatalkorú társadalmi reintegrációja megvalósuljon, és ne kövessen el újabb búncselekményt.

\section{A pártfogoltak jellemzői két kutatás tükrében}

Ahhoz, hogy a pártfogó felügyeletet a pártfogó felügyelők hatékonyan végre tudják hajtani a céloknak megfelelően, szükséges feltárni a pártfogoltak jegyeit, ismerni a legtipikusabb jellemzóket, körülményeket. A pártfogó felügyelet az alanyait tekintve jóval vegyesebb összetételű lehet, mint a például a javítóintézetek növendékei. Ez a jelenség leginkább a kockázatértékelés következtében rajzolódik ki. A sokproblémás, szegregált környezetben, diszfunkcionálisan működô családokban élő fiatalok esetében a kriminalitás szempontjából magasabb a 
veszélyeztetettség, mint egy olyan fiatal esetében, aki rendezett lakhatási körülményekkel, és rendezett családi háttérrel rendelkezik. A továbbiakban két kutatás alapján ismertetjük a pártfogoltak főbb jellemzőit.

Dávid (2013) a Baranya Megyei Igazságügyi Hivatal Pártfogó Felügyelói Szolgálatnál végzett kutatást a pártfogolt fiatalok főbb jellemzőire tekintettel. A 2006-ban iktatott fiatalkorúak pártfogó felügyelete során készült aktákat (303 akta) tekintette át egy nyitott és zárt kérdéseket tartalmazó kérdőív segítségével. 2011-ben a bűnügyi nyilvántartásban újra áttekintette ugyannak a 303 fiatalnak az aktáját annak érdekében, hogy a pártfogó felügyelet eredményességét mérje. A kutatásnak azon részeit kívánjuk összegezni, amik a legjelentősebbek a témánk szempontjából.

A kormegoszlás vonatkozásában az általa vizsgált legfiatalabb pártfogolt 14 éves, a legidősebb 21 éves volt, amikor pártfogó felügyelet alá került. Az iskolázottság tekintetében befejezett nyolc általános iskolai végzettsége 96 főnek volt, kilenc osztálya 52 főnek, és három fônek a legalacsonyabb iskolai végzettsége négy osztály volt. A pártfogó felügyelet kezdetén 139 fő folytatott iskolai tanulmányt, míg tanulmányokat már nem folytató pártfogoltak esetén csupán 15 fő rendelkezett szakmával, és 146 főnek nem volt szakmai képesítése. A tanuláshoz és munkához való hozzáállás esetében 190 főnek volt átlagos és 84 fônek volt negatív hozzáállása. A pártfogoltak legnagyobb arányban a szüleikkel élnek (114 fö), lakhatási körülményeiket tekintve 160 főnek megfelelö/átlagos/jó, 39 fó esetében pedig komfort nélküli volt. Az anyagi helyzetet vonatkozásában 94 főnek rossz, 98 főnek jó és 38 főnek átlagos volt. A szabadidős elfoglaltság esetében csupán nyolc főnél jelent meg hasznos szabadidô eltöltés pl. sport, rajzolás, vagy zenélés.

Legnagyobb arányban a vagyon ellen elkövetett bủncselekmények vannak jelen. 264 esetben lopás valósult meg. A bűncselekmény elkövetésének a leggyakoribb oka az alkoholprobléma, a kortárs- közösség negatív hatása, illetve a kedvezőtlen anyagi körülmények voltak.

A három leggyakoribb külön előírt magatartási szabály az iskolai tanul-mányok folytatására, az igazolatlan hiányzá-sokra, és a kábítószerhasználtra vonatkozott. A pártfogó felügyeletet 213 esetben nyilvánították a pártfogó felügyelôk eredményesnek és 78 esetben nem tartották annak. A magatartási szabályokat 206 fő tartotta be és 37 fó pedig nem. A bűnismétlésre tekintettel 139 főnél a pártfogó felügyelők nem említenek veszélyeztető körülményt, 164 főnél fenn áll a bűnismétlés esélye. A 2011-ben újra elővett akták esetében 47,85\%-uk követett el újabb bűncselekményt, tehát a fiatalok közel felénél a pártfogás, mint tercier prevenció nem járt eredménnyel (Dávid, 2013).

A téma másik jelentős képviselője Kerezsi Klára (2008), kriminológus Kó József (2008), szociológussal közösen végzett kutatást a fiatalkorúakkal szemben alkalmazott feltételes ügyészi felfüggesztés, javítóintézeti nevelés, illetve a végrehajtandó szabadságvesztés hatékonyságát illetően. Végeztek kérdőíves felmérést 143 javitóintézetből elbocsátott és 220 feltételes ügyészi felfüggesztés alatt álló fiatalkorú körében, másrészt ügyforgalmi statisztikai adatokat elemeztek. A kutatásból láthatóvá válnak a pártfogó felügyelet alatt álló fiatalok és a volt javítóintézeti növendékek közötti legjelentősebb különbségek. A megkérdezett korosztály 16-24 éves fiatalok voltak. A kutatás azon eredményeit összegezzük, amelyek a tanulmány függvényében jelentősebbek. A kérdőíves megkérdezés eredményeinek tekintetében a munkaerôpiaci helyzettel kapcsolatban a két csoport foglalkozása között nincs jelentős különbség, a fiatalok többsége segéd- vagy betanított munkás.

Az iskolázottság vonatkozásában a feltételes ügyészi felfüggesztés alatt állók magasabb iskolai végzettséggel rendelkeztek, különösen szakközépiskolát, gimnáziumot végeztek, a javítóintézetből elbocsátottat esetében a szakmunkásképesítés volt inkább a jellemző. 
A javítóintézeti elbocsátottak 14,7\%-a nem fejezte be az általános iskolai tanulmányaikat, a másik csoport esetében ez az arány 8,6\%. A két csoport alkoholfogyasztás területén hasonló szokásokkal rendelkezett, a többség alkalmi fogyasztónak vallotta magát. A drogfogyasztásról csupán két-két fiatal számolt be. Ennek oka lehet, hogy a drogfogyasztás bűncselekménynek minősül, és ezzel a fiatalok is tisztában vannak, tehát lehetséges, hogy a valóságban nagyobb arányban van jelen ez a probléma. A családi kapcsolatokat tekintve a kutatás alapján az mondható el, hogy a javítóintézetból elbocsátott fiatalok családi kapcsolata rosszabb, mint a feltételes ügyészi felfüggesztés alatt állóké (Kerezsi és Kó, 2008).

A kutatások alapján összességében elmondható, hogy a pártfogoltak többségére leginkább jellemző az alacsony iskolázottság, a szabadidő hasznos eltöltésének hiánya, az elkövetett bűncselekmények okát tekintve veszélyeztető tényezóként van jelen az alkoholfogyasztás, a kortársak negatív hatása, és az anyagi problémák.

A pártfogó felügyelet során szükséges az adott esetben megjelenő leginkább veszélyeztető problémának megoldását középpontba helyezni annak érdekében, hogy a pártfogó felügyeletet eredményesen tudják végrehajtani.

\section{A pártfogó felügyelet hatékonyságának vizsgálata}

A kutatás célja, hogy feltárjuk azokat a diszfunkciókat, amiknek hatására a fiatalkorúak elkövették a bűncselekményt és ezeket a szekunder és tercier prevencióra vonatkoztatva vizsgáljuk. A kutatás további célja a pártfogó felügyelet hiányosságainak, erősségeinek, a feltárása, illetve a szekunder prevenció során felmerülő nehézségek vizsgálata. Továbbá, melyek azok a problémák, amik különös odafigyelést igényelnek a szekunder prevenciós tevékenység során. Jelen tanulmányban a kutatásnak azon részét fejtjük ki, amely a pártfogó felügyelettel kapcsolatos tapasztalatokat vizsgálja a fiatalkorúak oldaláról.

A kutatást 2018 májusa és szeptembere között végeztük az EMMI Debreceni Javítóintézetében, illetve a Hajdú- Bihar Megyei Pártfogó Felügyelői Szolgálatnál. Alapsokaságként olyan fiatalkorú bűnelkövetőket jelöltünk meg, akik a tercier prevenció alanyai, és akik vagy voltak pártfogás alatt, vagy jelenleg is pártfogás alatt állnak. Kvalitatív kutatás keretében 25 fơvel készült félig strukturált interjú. Közülük 10 fő jelenleg is pártfogás alatt áll és a családjával él, őket a továbbiakban pártfogoltaknak nevezzük, illetve 15 olyan javítóintézetben élő növendékkel készítettünk interjút, akik a javítóintézetbe kerülésük előtt pártfogás alatt álltak. Ez utóbbi csoportot a továbbiakban növendékeknek nevezzük. A javítóintézeti növendékek közül kiválogattuk, hogy kik álltak pártfogás alatt a bekerülésük előtt. Csak azoknak a növendékeknek neve került fel a listára, akik önkéntes alapon vállalták az interjún való részvételt. A kész lista után szisztematikus mintatétel segítségével választottuk ki az alanyokat. A pártfogoltak esetén is szisztematikus mintavételt alkalmaztunk a Pártfogó Felügyelői Rendszer adatai alapján. A növendékekre vonatkoztatva arra kerestük a választ, hogy milyen diszfunkciók léptek fel a pártfogó felügyelet során, ami miatt a pártfogó felügyelet nem tudta elérni célját, illetve a pártfogoltakra vonatkoztatva milyen segítséget nyújt, és hogyan értékelik a pártfogó felügyeletet a fiatalkorúak.

$\mathrm{Az}$ interjúk rögzítése a növendékek esetén nevelői szobában, tanácsteremben, illetve a folyosón történt attól függően, hogy a csoport az adott időpontban hol tartózkodott. A növendékek esetén nem volt jelen zavaró tényezó, a négyszemközti interjú biztosítva volt. A pártfogoltak esetén több nehézség is adódott. Egyrészt nehezen tudtuk megtalálni az interjúalanyokat, másrészt zavaró tényezők is megjelentek az okból, hogy az interjúk a pártfogoltak lakóhelyén került rögzítésre (a házban, a ház oldalában, az árok szélén, vagy az 
KÜLÖNLEGES BÁNÁSMÓD, V. ÉVF. 2019/3.

udvaron rögzítettem az interjúkat). Volt, akinek a szüleivel is tudtunk beszélgetni -kutatáson kívül -, illetve több pártfogoltnak a lakásában is jártunk.

A kutatás során több befolyásoló tényezővel is számolnunk kellett. Ilyen tényező volt az impressziókeltés. Egyes interjúalanyok látható módon igyekeztek a lehetőségeikhez mérten minél jobb benyomást kelteni magukról. Másik tényező, amivel számolnunk kellett, hogy lehetséges, az egyes interjúalanyok torzítják a valóságot, nem, vagy csak félig mondanak igazat. Több interjúalanynál is probléma volt a szúkszavúság, aminek részben a nyelvi hátrány lehet az oka. Másik befolyásoló tényező a minta nagysága, ami mindenképpen korlátozza a kutatási következtetések kereteit. Mivel viszonylag kis mintával volt lehetôségünk dolgozni (összesen 25 fő), így természetesen a levont következtetéseket minden pártfogoltra és növendékre vonat- koztatva nem tekinthetjük törvényszerúnek. A továbbiakban bemutatjuk a kutatásunk pártfogó felügyelettel kapcsolatos eredményeit.

\section{Kormegoszlás, büncselekménytípus}

A korosztályok tekintetében a legfiatalabb interjúalany 15 éves, a legidősebb 18 éves volt. Az 1. táblázatban az interjúalanyok kormegoszlását mutatjuk be. A pártfogoltaknál a megkérdezettek közül a 10 főbooll 3 fó lány és 7 fó fiú volt, a növendékeknél minden alany fiú volt.

A bủncselekménytípusok tekintetében a legtöbben vagyon elleni búncselekményeket követtek el. Növendékek esetén 8 fô lopást, 6 fô rablást, 1 fó sikkasztást, a pártfogoltak esetén 5 fő lopást, 4 fö testi sértést, 1 fö közveszéllyel fenyegetést követett el.

2. táblázat. A minta kormegoszlása. (Forrás: saját szerkesztés)

\begin{tabular}{|c|c|c|}
\hline Kor & Növendékek & Pártfogoltak \\
\hline 15 éves & 4 fö & 1 fö \\
\hline 16 éves & 4 fö & 3 fö \\
\hline 17 éves & 6 fö & 4 fö \\
\hline 18 éves & 1 fö & 2 fö \\
\hline
\end{tabular}

Fiatalkorúak pártfogással kapcsolatos tapasztalatai.

A pártfogó felügyelettel kapcsolatban azt vizsgáltuk, hogy milyen problémák jelennek meg a tevékenység során, amik gátolják a pártfogó felügyelet céljainak megvalósulását. A pártfogás alatt állt növendékek és a pártfogó felügyelet alatt álló fiatalok szubjektív tapasztalataik, véleményeik rajzolódtak ki. A növendékek és a pártfogoltak között több különbség is mutatkozott. Először a növendékeknél megjelenő tapasztalatokat, véleményeket ismertetjük.
„Két évig pártfogó alatt voltam, és volt olyan, hogy nem tartottam vele a kapcsolatot ezele a dolgok miatt fü, meg ilyenek... Kérdezte, hogy hogy vagyok, mit csinálok, meg bogy telnek a napjaim, mit csinálok, ennyi volt." (4. növendék)

„Nem volt vele semmi baj, de megmondom öszintén, hogy nem sokat jártam hozzá, 2 bónapot talán.” (9. növendék)

„Ö egyszer volt nálam, de akekor se voltam otthon, keresett, sose talált meg. Volt, hogy hivott, de nem akartam menni, nem érdekelt." (11. növendék) 
KÜLÖNLEGES BÁNÁSMÓD, V.ÉVF. 2019/3.

A növendékeknél 12 esetben a pártfogó felügyeló nem tudott érdembeli segítséget nyújtani, közönyösen viszonyultak hozzá a növendékek, illetve jellemző volt, hogy ritkán találkoztak, így érthető, hogy miért nem tudta a pártfogó felügyelet elérni a célját.

Abban a három esetben, ahol a pártfogó tudott valamilyen segítséget nyújtani leginkább a pártfogóval történő beszélgetés jelent meg konkrét pozitív emlékként.

„Szerettem, mert egy szép nő volt... Normális hölgy volt, meg sok jókat mondott, hogy hát ezeket nem kellene csinálni, mert eq csak rossz útra visz:” (13. növendék)

„Hát, elég sürün találkoztam vele. Volt, hogy magamtól mentem be. Elég jó volt a kapcsolatom, pl. ha az. iskolába adott igazolás, vagy ha volt valami bajom volt, hogy felhivtam és lejött beszélni." (10. növendék)

Konkrét negatív élmény 2 esetben jelent meg. Elsődlegesen az állandó kontroll, ellenôrzés volt az, ami negatív tapasztalásként maradt meg bennük.

„Nem kedveltem, mindig azt nézte, hogy be vagyok-e állva... állandóan zaklatott, egy szabad hetem nem volt töle." (12. növendék)

„Óóó, csak a bülyeséget beszélte, hogy el fog vitetni meg ilyenek, de szerinted ez engem hol érdekelt. Mondja, hogy „el foglak vitetni”, mert nem járok iskolába..." (14. növendék)

Ebben a két esetben a probléma forrása az lehetett, hogy csupán az ellenőrzés volt jelen, de érdembeli segítséget a pártfogó nem tudott nyújtani pl. a drogprobléma kezelésével kapcsolatban. A kutatás során az is kiderült, hogy a pártfogó felü- gyelet és az azzal együtt járó magatartási szabályok nem bizonyultak visszatartó erőnek. Az alanyok nem érezték azt, hogy következményekkel járhat a szabályok megszegése. A speciális magatartási szabályok, amelyek lényegében egyénre szabottak, önmagukban tapasztalható módon kevésbé tudnak sikert elérni. Példának okául a szerfüggőség esetén pusztán a tiltás kevésnek bizonyul, szükséges a probléma kezelésében kompetens intézmény bevonása.

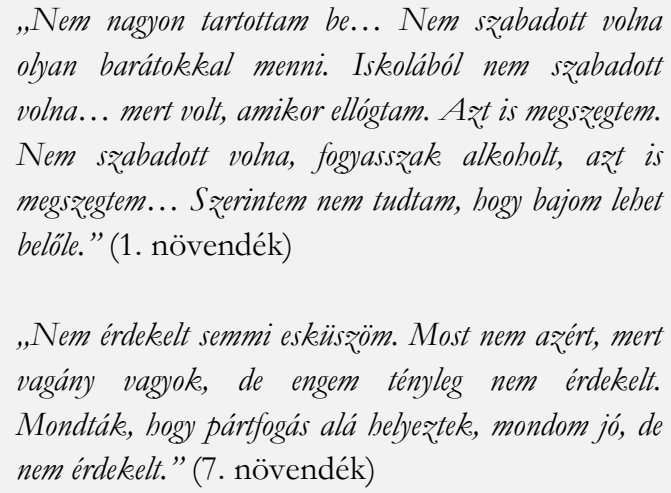

Az utóbbi esetből kifolyólag feltehetô az a kérdés, hogy az alternatív szankciók képesek-e a támogatás mellett visszatartó erőként funkcionálni, megfelelő kontrollt gyakorolni, mivel a szabálysértés, vagy bủncselekmény elkövetése következtében elrendelt pártfogó felügyeletnek egyik fố célja, hogy megelőzzék az ismételt elkövetést.

A magatartási szabályok be nem tartására a 3 . növendék azt az okot adta, hogy ő ehhez volt hozzászokva. Az ő esetében is megjelent az iskolakerülés, a drogfogyasztás, és a csavargás, ami már szokványossá vált az életében. Ezeknek a berögzült elemeknek a kezelése komplex megoldást igényel, amit önmagában a pártfogó felügyelő nem tud végrehajtani.

A növendékek után tekintsük át a jelenleg pártfogás alatt álló fiatalok tapasztalatait, véleményeit. A pártfogoltak a növendékekhez képest jóval több 
pozitív tapasztalattal rendelkeztek a pártfogó felügyeletet illetôen, azonban konkrét segítséget ôk is kevésbé kaptak. Elsődlegesen pozitívként a pártfogóval történő beszélhetés jelent meg. A pártfogó egyfajta támaszt tudott nyújtani számukra.

„Van, hogy ö jön, de volt olyan is, hogy mi mentünk anyuval... Elbeszélgetünk mindig, ha találkozunk.” (4. pártfogolt)

„Hát, xy bácsi (a pártfogó) a legfainabb. Hát, akárki akármit mond nekem. Amúgy is vártam már mikor jọjön." (7. pártfogolt)

„Úúu bát, az spanom, jó, nagyon rendes... Elmondom neki is a dolgaimat. Segit, hogy mit csináljak, bemegyek bozzá, megcsinálom, most tényleg be fogok menni hozzá, mert van ez a közmunka." (6. pártfogolt)

A pártfogoltaknál a konkrét segítségnyújtás hiányának az oka elsődlegesen az volt, hogy a pártfogoltak úgy érzik, nem igazán van szükségük segítségre. A megkérdezettek közül 8 esetben jelent meg az, hogy nekik nem tud miben segíteni a pártfogó. E mellett szükséges kiemelni azt, hogy az összes megkérdezett hátrányos vagy halmozottan hátrányos családból származik, amiből kifolyólag több-kevesebb nehézség megjelenik az életükben. Ezek alapján levonható a következtetés, hogy a pártfogoltak nem teljesen vannak tisztában saját helyzetükkel.

„Hát, úgy igazán nem volt semmi, amiben kellett volna (segiteni).” (4. pártfogolt)

„Nem kell nekem segitség, van munkám.” (8. pártfogolt)
A maradék két esetben a pártfogó egyrészt munkaügyileg tudott segítséget nyújtani, a másik pártfogoltnak a drogproblémája miatt lenne szüksége segítségre, azonban ő úgy érzi, hogy a pártfogó nem érti meg ôt, és nem tud neki segíteni ebben, pedig igényelné a segítségét.

„Már a múltkor is segitett, a sajtgyárat, ott lett volna munka csak nem mentük el, mert kiderült, hogy nem lehet cigizni.” (9. pártfogolt)

„Úgy éreatem, hogy nem ért meg engem, hiába mondom el, úgyse tud semmit se csinálni nem tud segíteni." (1. pártfogolt)

Az első eset példája annak, amikor a pártfogó felügyelő igyekszik segítséget nyújtani, de a pártfogolt önhibájából nem él a lehetôséggel. Az 1. pártfogolt esetében megtörtént a kompetens szakemberekhez való irányítás, de a pártfogolt nem volt együttmúködő.

A 2. táblázatban a növendékek és a pártfogoltak pártfogó felügyelettel kapcsolatban felmerülő tapasztalatok közötti különbségeket foglaljuk össze.

A pártfogók munkáját nagyban megnehezíti az, hogy sok pártfogolt nem látja át a saját helyzetét. A tanulás felé nagyon alacsony a motivációjuk, illetve sokszor próbál a pártfogó segíteni, azonban a pártfogolt önhibájából kifolyólag nem él ezzel a lehetőséggel. A pártfogók munkáját nehezíti még a leterheltségük, ami a dokumentációban, és az egy pártfogóra eső magas pártfogoltak számában merül ki. Ezekből kifolyólag a rendszeres kapcsolattartás is nehézségekbe ütközik, ami szintén akadályozza a pártfogó felügyelet céljainak elérését. 
KÜLÖNLEGES BÁNÁSMÓD, V.ÉVF. 2019/3.

3. táblázat. A növendékeek és a pártfogoltak pártogó felügyelettel kapcsolatos tapasztalataik közötti különbségek. (Forrás: saját szerkesątés).

\begin{tabular}{|c|c|c|}
\hline Tapasztalatok & Növendékek & Pártfogoltak \\
\hline Ritkán találkoztak & 5 esetben & 2 esetben \\
\hline Nem tudott segítséget nyújtani & 12 esetben & 8 esetben \\
\hline Konkrét pozitív élmény & 3 esetben & 10 esetben \\
\hline Konkrét negatív élmény & 2 esetben & 1 esetben \\
\hline
\end{tabular}

A pártfogó felügyelet hatékonyságának növelése érdekében tett javaslatok a kutatás alapján.

A kutatás során felmerült problémák alapján javaslatokat kívánunk megfogalmazni a pártfogó felügyelet hatékonyságának növelése érdekében. A javaslatok mellett szükségszerűnek gondoljuk egyes problémakörökre felhívni a figyelmet, amik fokozott odafigyelést igényelnek. Fontosnak tartjuk kiemelni, hogy a problémaként megjelölt tényezők nem törvényszerűen jelennek meg minden esetben, de egyes esetekben, mint ahogy a kutatásban is megmutatkozott, megjelenhetnek, ebből kifolyólag igyekszünk felhívni ezekre a tényezókre a figyelmet. A javaslatokat az 3. táblázatban foglaljuk össze. Mint, ahogyan a kriminalitási gyakoriság megyénként eltérő tendenciát mutat, úgy a pártfogó felügyelők terhei is ezek alapján változnak. A Búnügyi Statisztika Rendszer (2018) adatai alapján Budapest, Borsod-Abaúj-Zemplén megye,
Szabolcs-Szatmár-Bereg megye, Hajdú-Bihar megye esetében kirivóan magas a többi megyéhez képest a búnelkövetők száma. A magas kriminalitási gyakoriság intenzívebb problémakezelést, több munkát von maga után, amit nagyban segíthet az egy pártfogóra eső pártfogoltak számának csökkentése például a pártfogó felügyelôk számának növelése révén. A speciális magatartási szabályok betartása mindenképpen külső segítséget igényel, ezekhez szükséges bevonni a kompetens intézményeket.

Alkoholprobléma, drogfüggőség esetén szenvedélybetegek ellátásával foglalkozó intézmények, iskolai nehézségek esetén mentorprogramok felkeresése, és a tevékenységben történő intenzív együttmúködés szükséges. A magatartási szabályok betartását segítheti a szabály funkciójának, okának intenzív tudatosítása a pártfogoltban. A pártfogó felügyelőknek a munka során fontos fókuszban tartaniuk a bűncselekményhez vezető okokat.

4. táblázat. Javaslatok a kutatás alapján. (Forrás: saját szerkesztés).

\begin{tabular}{l|l}
\hline \multicolumn{1}{c}{ Probléma } & \multicolumn{1}{c}{ Megoldási javaslat } \\
\hline Nem megfelelő intenzitású kapcsolattartás. & \multicolumn{1}{c}{$\begin{array}{l}\text { Pártfogó felügyelök terheinek csökkentése: elsődlegesen az } \\
\text { egy pártfogóra eső pártfogoltak számának csökkentése révén. }\end{array}$} \\
\hline $\begin{array}{l}\text { Magatartási szabályok betartásának prob- } \\
\text { lematikája. }\end{array}$ & $\begin{array}{l}\text { Intenzív kapcsolattartás a kliensekhez köthető szervekkel. Az } \\
\text { egyes problémák felismerésekor jelzés és kapcsolatfelvétel a } \\
\text { kompetens intézménnyel. }\end{array}$ \\
\hline Esetenként megjelenő túl erős kontroll, & $\begin{array}{l}\text { Elsődlegesen törekvés a probléma pontos definiálására és } \\
\text { megoldására. }\end{array}$ \\
kevés segítő, támogató tevékenységgel. & $\begin{array}{l}\text { Aktuális élethelyzet és alternatívákhoz vezető út intenzív } \\
\text { Irreális helyzetfelismerés a pártfogoltak ré- } \\
\text { széről. }\end{array}$ \\
\hline
\end{tabular}


Ezeket a problémákat a már többször említett kompetens szervek bevonásával szükséges kezelni. Úgy gondoljuk, hogy a cél elérése érdekében elsődlegesen a segítségnyújtást szükséges előtérbe helyezni, és a kontroll szerepet másodlagosan gyakorolni.

A kutatás során megmutatkozott, hogy sok esetben a pártfogoltak nem mindig vannak tisztában a saját helyzetükkel, nem látnak más alternatívákat. A pártfogó felügyelők a pártfogolt körülményeinek megismerése után felállított lehetséges megoldások folyamatos tudatosításával, és a célok eléréséhez szükséges erőfeszítések támogatásával jelentős mértékben tudják segíteni a pártfogolt reális helyzetfelismerését és változás iránti motivációját.

A javaslatokon kívül szeretnénk továbbá felhívni a figyelmet olyan tényezókre, amik fokozott odafigyelést igényelnek annak érdekében, hogy megelőzzük a kriminális magatartás kialakulását, illetve az ismételt bűncselekmény elkövetését. A fiatalkorúakkal kapcsolatba kerülő szervek fokozott együttmúködése szükséges. Az iskolák, a család- és gyermekjóléti szolgálatok, szenvedélybetegekkel foglalkozó alapellátások, pártfogó felügyelők és minden egyéb intézmény aktív, összehangolt kommunikációja és egymás tevékenységének támogatása segítni a közös célok elérését. E mellett egy másik tényezőre is szeretnénk felhívni a figyelmet, ami a szegregáció problematikája. A leszakadó, hátrányos helyzetű települések, településrészek lakói fokozottabban ki vannak téve a kriminalitás veszélyeinek, hiszen ezeken a területeken nagyobb eséllyel jelennek meg a különböző devianciák. A szegregált területek felzárkóztatására hazánkban számos jó gyakorlat jött létre, ilyen a BAGázs Közhasznú Egyesület, vagy a Világítani Fogok Egyesület tevékenysége, továbbá civil vonal mellett, az utóbbi időben számos központi törvekvés jelent meg a felzárkóztatás céljával (pl.: Arany János Tehetséggondozó Program).

\section{Összegzés}

A tanulmányban áttekintettük a pártfogó felügyelet múködését, két kutatás alapján a pártfogoltak személyét, jellemzőit, illetve bemutatásra került saját empirikus kutatásunk egyik részeleme, ami alapján javaslatokat fogalmaztunk meg. Látható, hogy a pártfogó felügyelet számos akadályba ütközik a végrehajtás során, amiket szükségszerủen kezelni kell ahhoz, hogy a pártfogó felügyelet elérje a célját. Popper (1970) szerint a fiatalkorúak bűnmegelőzése a felnőtt korú bűnelkövetők prevenciója is egyben, ezért különösen fontos, hogy a preventív szervek megfelelő hatékonysággal tudjanak múködni annak érdekében, hogy a kriminalitás tekintetében veszélyeztetett fiatalok társadalmi integrációja biztosítva legyen.

\section{Köszönetnyilvánitás}

A tanulmány az Emberi Eróforrások Minisztériuma ÚNKP-18-1-I-DE-440 kódszámú új Nemzeti Kiválóság Programjának támogatásával készült.

\section{IRODALOM}

Bogschütz Zoltán, Kóta Tünde és Velez Edit (2009): A pártfogó felügyelet mint közösségi büntetés. In: Borbíró Andrea és Kerezsi Klára (szerk.): A kriminálpolitika és a társadalmi bünmegelơzés kéziköonyve II. Fresh Art Design Kft, Budapest. 197-240.

Dávid Lilla (2013): A hazai pártfogó felügyelet intéz̨kedésének szerepe a fiatalkorúak bünelkövetésének megelớééében. Pécsi Tudományegyetem Állam- és Jogtudományi Kar Doktori Iskolája, Pécs.

Herke-Fábos Barbara Katalin (2018): A megelőző pártfogás szerepe a bűnmegelőzésben. Párbeszéd, 5. 1. 32-51.

Kerezsi Klára és Kó József (2008): A fiatalkorúak büntető igazságszolgáltatásának hatékonysága. Kriminológiai tanulmányok, 45. 93-148. 
Kerezsi Klára, Kovács Krisztina, Párkányi Eszter és Szabó Judit (2015): A pártfogó felügyelet szerepe a búnmegelőzésben, különös tekintettel a jogintézmény tervezett változásaira. In: Vókó György (szerk.): Kriminológiai Tanulmányok. Országos Kriminológiai Intézet, Budapest. 148191.

Kerezsi Klára (2016): Alternatív szankciók és közösségben végrehajtott büntetések. In: Bíró Andrea, Gönczöl Katalin, Kerezsi Klára, és Lévay Miklós (szerk.): Kriminológia, Wolters Kluwer, Budapest. 910-929.

Popper Péter (1970): A kriminális személyiségzavar kialakulása. Akadémiai Kiadó, Budapest.

Rákó Erzsébet (2011): A gyermekvédelmi szakellátás helyzete. Debreceni Egyetemi Kiadó, Debrecen.

Rosta Andrea (2014): A fiatalkorú bünözés kriminologiája és szociológiaja. L'Harmattan Kiadó, Budapest.
Bűnügyi Statisztikai Rendszer (2018): Elkövetők, bűnelkövetők száma az elkövetô lakóhelye szerint 2013.01.01-2018.06.30 Link: https://bsr.bm.hu/Document letöltés dátuma: 2018.10.11

\section{Jogforrás}

1997. évi XXXI. törvény a gyermekek védelméről és a gyámügyi igazgatásról

2012. évi C. törvény a Büntető Törvénykönyvről

8/2013. (VI. 29.) KIM rendelet a Pártfogó

Felügyelői Szolgálat tevékenységéről

2017. évi XC. törvény a büntetőeljárásról 